\title{
THE STATUS OF EQUAL OPPORTUNITIES OMBUDSMAN IN THE REPUBLIC OF LITHUANIA: SELECTED PROBLEMATIC ISSUES
}

\author{
INGA $\check{Z}_{A L E} \dot{E}_{\text {IEN }} \dot{E}^{*}$ \\ DANGUOLE் GRIGOLOVIČIENË ${ }^{* *}$
}

\section{INTRODUCTION}

The common principle of equality is set forth in Article 29 of the Constitution of the Republic of Lithuania. Implementation of this fundamental principle is set out in detail in the norms of various fields of law, including special legislation, which forbid discrimination on the grounds of sex, age, sexual orientation, disability, race, ethnic origin, religion, believes, social status and other criteria. The main acts regulating the implementation of this principle are the Act of the Republic of Lithuania on Equal Treatment ${ }^{1}$ and the Act of the Republic of Lithuania on Equal Opportunities for Women and $\mathrm{Men}^{2}$. These are special pieces of legislation which implement the European Union's anti-discrimination Directives in Lithuania. The office of Equal Opportunities Ombudsman operates in order to supervise the process of implementing these laws. This institution is overseen by the Lithuanian Parliament and was established in 1999 as the Office of the Ombudsman for Equal Opportunities for Women and Men, and following adoption of the Equal Treatment Act in 2005 it was renamed as the Equal Opportunities Ombudsman's Office.

It is a paradox, but in the Lithuanian legal system there is no definite attitude to the legal force of decisions by the Equal Opportunities Ombudsman's Office, frequently the question is raised of whether these decisions can be appealed. This is a very serious problem as the number of discrimination cases heard in courts is growing, and judicial practice in this field risks becoming highly inconsistent. If this situation remains

DOI: $10.1515 /$ wrlae-2015-0001

* PhD; Professor of Institute of Constitutional and Administrative Law; Mykolas Romeris University; izaleniene@mruni.eu

** Senior Advisor of the Office of the Equal Opportunities Ombudsman; dagrig@1rs.1t.

${ }^{1}$ The Law on Equal Treatment of Republic of Lithuania [2003] OJ 114-5115.

2 The Law on Equal Opportunities of Women and Men of Republic of Lithuania [1998] OJ $112-3100$. 
unresolved, there is a danger that the trust of society in the Equal Opportunity Ombudsman may face serious decline, and people who suspect that they have been discriminated against will not rely on this institution because of the legal insignificance of its decisions. This ambiguous situation has encouraged the authors to pose the following scientific question: what is the legal force of the Ombudsman's decisions, and can they be appealed? The main task of this paper is to determine the legal force of the Equal Opportunities Ombudsman's decisions and the possibility of challenging them. For this purpose it is intended to: 1) analyse the fundamental regulation of the Equal Opportunities Ombudsman Office's activities; 2) identify the main types of decisions taken by the Equal Opportunities Ombudsman; 3) determine the legal power of those decisions and the possibilities to appeal them from the perspective of positive law.

In this article the dominant analytical methodology is pragmatism. The main methods of research are scientific literature analysis, descriptive, analytical, teleological and comparative methods, and document analysis. By applying scientific literature analysis, the authors reveal the present attitude of science to the relevant issues and provide a theoretical background for analysis of legislation (document analysis). Descriptive, analytical and teleological methods were used to reveal the current legal situation and identify problems and possible solutions related to the issue of uncertainty over the legal force of decisions by the Equal Opportunities Ombudsman. Comparative methodology was used to identify the status of the Equal Opportunities Ombudsman in Lithuania and to compare it with other possible institutional guarantees existing in Europe for implementing the principle of equality.

It is worth mentioning that the principle of equality and the main aspects surrounding its implementation (including the legal status of the Equal Opportunities Ombudsman) have already been analyzed by several Lithuanian scholars (such as A. Abramavičius, T. Birmontienè, T. Davulis, D. Gumbrevičiūtè- Kuzminskienè, K. Jovaiša, E. Kūris, I. MačernytėPanomariovienè, B. Pranevičienè, A. Vaišvila, S. Vidrinskaitè, E. Žiobienè and A. Žvinklienè). However, these researchers did not focus their efforts on the activities of the Equal Opportunities Ombudsman, and while they have analysed particular issues concerning this institution, they have not identified the uncertainty of the legal force of its decisions, nor have they searched for possibilities to clarify this ambiguous regulation in positive law. Also it should be noticed that this issue was never raised in international area. As a result, it may be said that the legal force of the Lithuanian Equal Opportunities Ombudsman's decisions and possibilities for appealing them have not been analysed in scientific literature. This is why the chosen topic is new and relevant to current legal practice as well as to legal science. 


\section{THE FUNDAMENTAL REgULATION OF THE ACTIVITY OF THE EQUAL OPPORTUNITIES OMBUDSMAN'S OFFICE}

The requirement to ensure equal opportunities and the prohibition of discrimination is established in a range of important international documents which must be applied in all European Union Member States. Mention must be made of the Universal Declaration on Human Rights ${ }^{3}$, the European Convention on Fundamental Human Rights and Freedoms ${ }^{4}$, the International Covenant of Social, Cultural and Economic Rights ${ }^{5}$ and the Treaties of the European Union ${ }^{6}$. Despite clear prohibitions against violating the principle of equality among people, discrimination (representing the polar opposite of equality) is still common in contemporary society ${ }^{7}$. Since 1970, legal scholars and practicing lawyers have observed that the mere adoption of certain legal acts is not enough for the proper implementation of the principle of equality. This is why most EU Member States have decided to establish certain institutions to stimulate "a model of alternative behaviour" in order to achieve effective implementation of antidiscrimination law. Institutions which implement the principle of equality can be treated as measures helping governments to implement the norms of equality as effectively as possible ${ }^{8}$. It is worth noting that only the United Kingdom, Ireland and Belgium had such institutions prior to adoption of European Council Directive 2000/43/EC (the Racial Equality Directive). This EU legal act (particularly Article 13) provides uniform conditions for applying this principle to all people regardless of their racial or ethnic status. The Racial Equality Directive establishes minimum requirements for equality institutions, whose main task is to act independently and help discriminated people by formulating conclusions, undertaking research on equality, and issuing reports and recommendations concerning all discrimination-related matters. According to the Racial Equality Directive EU Member States have the right to make their own decisions on the questions of the structure and functions of their equality institutions, in accordance with their legal traditions and political decisions ${ }^{9}$.

In 1997, work was begun on creating an institutional mechanism for ensuring equal opportunities for women and men in Lithuania ${ }^{10}$. Article 9 of

\footnotetext{
${ }^{3}$ Universal Declaration of Human rights [2006] OJ 68-2497.

${ }^{4}$ The Convention of fundamental human rights and freedoms [1995] 40-987.

${ }^{5}$ International Covenant of Social, Cultural and Economic Rights [2002] 77-3290.

6 Treaty establishing the European Economic Community [1957]; Treaty on European Union [1992] OJ C 191.

${ }^{7}$ Ricardo Hausmann, Laura Tyson, Saadia Zahidi et al., The Global Gender Gap Report (World Economic Forum 2009).

${ }^{8}$ Dagmar Schiek, Lisa Waddington and Mark Bell, Cases, Materials and Text on National, Supranational and International Non - discrimination law (Hart Publishing 2007).

${ }^{9}$ Jonas Malmberg, 'Effective enforcement of EC Labour Law - A comparative analysis of Community law requirements for national laws on procedures and sanctions' (2004) 2 European Journal of Industrial Relations 10.

${ }^{10}$ Ona Gražina Rakauskienė, Aušrinè Burneikienè et al., Public Policy on the Aspect of Gender Equality (Mykolas Romeris University 2005).
} 
the Equal Opportunities for Women and Men Act provided that every physical and legal entity which felt that his/her rights had been violated has the right to lodge a complaint with the Equal Opportunities for Women and Men Ombudsman's Office. In Lithuania this institution was established on May 25, 1999 by the Parliament of the Lithuanian Republic. It was renamed in 2005 as the Equal Opportunities Ombudsman's Office following the adoption of a new Equal Treatment Act and extension of the functions of this institution. It should be noted that this office does not follow the classical model of an ombudsman acting solely in the field of public law. This body is authorised also to work in private law field and investigate cases, which take place not only in public sector, but also in private companies or society in general. The Equal Opportunities Ombudsman's Office (hereinafter the Office) is a special institution which analyses complaints from one group of people - namely, those affected by (perceived) violations of equality on the grounds of sex, race, ethnicity, nationality and other similar criteria. The establishment of this institution and the standards for its activities are guided by the Paris Principles of the United Nations.

In scientific literature an ombudsman is defined as an independent person or independent collegial institution established by a constitution or on the ground of special laws with a mission to defend the interests of those who believe that their rights have been violated by public institutions ${ }^{11}$. The purpose of an ombudsman's office is commonly excluded through the need of supervising the activity of the executive powers. According to D. Poška and I.Žvaigždinienè, in democratic countries the legislative branch has the right to supervise the activities of institutions of executive power and does so through ombudsmen's offices ${ }^{12}$. It is generally accepted that an ombudsman is an independent mediator. In the countries which have ombudsmen's offices, the opinion is held that the relationship between ombudsmen and parliaments should not be based on the principle of subordination. According to B. Pranevičienè, a parliament can only provide common guidelines for the activities of ombudsmen's offices ${ }^{13}$.

In scientific literature, two groups of such institutions are distinguished according to the extent of Ombudsman's activity,: classical and specialized. The latter group is characterised by their activity, which is narrower than the general field of human rights defence. In Lithuania there are two specialized ombudsmen: the Equal Opportunities Ombudsman and the Ombudsman for Children's Rights. It should be noted that in Article 18 of the Higher Education and Research Act, the Office of Academic Ethics and Procedures Ombudsman is envisaged (its powers and duties include the right to analyse complaints and initiate investigations in the field of violations of academic ethics and procedures). However, despite the need and importance of such an institution, the Office of Academic Ethics and Procedures was de facto established on 18 June 2013, when the Parliament of the Republic of Lithuanian appointed the Ombudsman of Academic

\footnotetext{
${ }^{11}$ Edita Žiobienè, 'Problems of the Legal Status of the National Equality Bodies' (2006) 90 (12) Jurisprudence.

12 Egidijus Kūris et al., Lithuanian legal institutions (Registrų centras 2011).

13 Birutė Pranevičienè, 'Ombudsman and Public Administration' (2002) 32 (24) Jurisprudence.
} 
Ethics and Procedures. The functioning of the Ombudsman of Academic Ethics and Procedures is very important for realizing the equality of sexes in science $^{14}$. It should be noted that there are many parallels between the powers of the Equal Opportunities Ombudsman and the Academic Ethics and Procedures Ombudsman. Presently the Equal Opportunities Ombudsman also engages in analysis of complaints about discrimination in the academic sphere. In the future such work will comprise the greater part of the authority of the Academic Ethics and Procedures Ombudsman.

In Lithuania, the specialized institution of the Equal Opportunities Ombudsman's Office, as a body supervising the implementation of the equality principle, acts according to the principles of legality, impartiality, democracy and justice ${ }^{15}$. According to Favilli, "independence of the institution is necessary for performing its role according to the Directives"16. Equality institutions are unique - they are enacted by law, so they are not a part of society and do not deputize for any social group's interests. Equality institutions also are not a part of government - they are unique institutions created to implement equal opportunities legislation ${ }^{17}$. The main aim of these institutions is to achieve cultural changes in society, to spread the equality principle through civil society, and to support victims ${ }^{18}$. The special status of these institutions becomes clearer in a national setting. In the opinion of A. Poška and I. Žvaigždinienè, an equality institution is "the independent mediator between government and people, the inspector of official activities and also the defender of human rights" ${ }^{19}$. Having in mind this particular status, it is obvious that the issue of authority is very important for the effectiveness of such institutions, and is composed of two elements: legal status and the trust of society.

Some European countries have separate institutions for various grounds of discrimination: sex, race, and in some cases disability, sexual orientation and religion ${ }^{20}$. Taking into account the examples of equality institutions in Great Britain, B. D. Jacobsen and E. O. Rosenberg performed a comparative analysis and estimated the advantages and disadvantages of institutions acting in respect of individual discrimination grounds and of multiple discrimination grounds. In their report, they stated that institutions addressing a number of discrimination grounds are more effective, because in this way more resources can be saved, more knowledge can be shared, and the ;potential to investigate cases of multiple discrimination is provided. It is also noted that in these institutions the risk of categorizing grounds according to a hierarchy inevitably grows ${ }^{21}$.

\footnotetext{
${ }^{14}$ Lyma Project results (BASNET forum 2012).

15 The decision of Parliament of Republic of Lithuania on the confirming the regulations of the Office of Equal Opportunities Ombudsman [2003] OJ 111- 4930.

${ }^{16}$ Chiara Favilli, 'Institution of a body for the promotion of equal treatment, provided for EU law' in European Union Law (2002).

${ }^{17}$ Equinet Annual Report (Equinet 2009).

${ }^{18}$ Schiek, Waddington, Bell (n 8).

19 Kūris et al. (n 12).

${ }^{20}$ Schiek, Waddington, Bell (n 8).

${ }^{21}$ Equinet Annual Report (Equinet 2006).
} 
It may be concluded, that specialized Lithuanian Equality Ombudsman's Office, having in mid its independence, the broad field of activity and other characteristics of its status, correspond the good practise standards of western countries. The model of a specialized Equal Opportunity Ombudsman's Office as chosen by Lithuania for matters of equality shows acceptance of the importance of issues being discussed issues by those involved in public policy and their acknowledgment that implementation of equality is a goal of prime importance.

\section{ANALYSIS OF COMPLAINTS AND TYPES OF DECISIONS TAKEN BY THE EQUAL OPPORTUNITIES OMBUDSMAN IN LITHUANIA}

Concrete metrics are needed for assessing the activity of the institution which, once achieved, could provide a basis for grading the institution's effectiveness. In this chapter the competence of the Equal Opportunities Ombudsman's Office will be briefly overviewed through research on its activity and complaints, as well as through identifying concrete types of decisions in legal acts while demonstrating their qualities and disadvantages.

Racial equality, as well as Parliament and Council Directive 2006/54/EC on the implementation of the principle of equal opportunities and equal treatment of women and men in matters of employment and occupation (recast) (the Sex Equality Directive), demands that the institutions implementing this principle should provide independent assistance to discriminated persons, but does not establish a particular form for this support. In Articles 12 and 18 the Law on Equal Opportunities of Women and Men declares that people who have experienced discrimination have the right to appeal to a court or special institution - the Equal Opportunities Ombudsman's Office, which is not a compulsory stage of a pre-trial investigation. In the process of the investigation performed by the Equal Opportunities Ombudsman, this body may help the discriminated person to give the prima facie circumstances in the case of discrimination heard in court. This encourages the victim to ask the court to place the burden of proof on the defendant ${ }^{22}$. Appealing directly to the court is purposeful for trying to achieve a compulsory decision such as compensation for moral damages, and also for exceeding the term of limitation for defending the violated right. For example, Art. 1 of the Labour Code of the Republic of Lithuania provides that refusing to give a job, changing essential working conditions, suspension or firing based on discriminative motives can be appealed to the court not later than one month after the fact. To comply with the rules of admissibility as stated in Art. 22 of the Code on Civil Procedure of the Republic of Lithuania (CPC), a complaint against violations of equality cannot be analysed reviewed by both the Equal Opportunities Ombudsman's Office and a court. Article 14 of the Equal Opportunities Law and Art. 21(1) (4) declare that the

${ }^{22}$ Diana Gumbrevičiūte-Kuzminskienè, 'The concept of shifting the burden of proof and the mechanism in the cases of employment discrimination' (2008) 110 (8) Jurisprudence. 
Ombudsman must refuse to hear a complaint which has already been presented for investigation to a court.

There is no strict and formal form for a complaint to the Office, so the possibility for anyone, who feels that they have been discriminated against, to make appeal has been simplified. It is related to the founding principles of the EU Directives, which forbid discrimination (e.g. Article 8 of The Racial Equality Directive). Article 12 of the Law on Equal Opportunities of Women and Men states that the Ombudsman analyses complaints about direct and indirect discrimination, harassment or sexual abuse, and provides objective and equitable consultations, concerning the issues mentioned above. The Ombudsman also carries out independent research, concerning cases of discrimination, and gives independent reviews of discriminatory situations in the country, announces independent reports, reaches conclusions and provides recommendations about any questions connected with implementing the equality principle. The ombudsman also makes proposals to public institutions or offices of the Lithuanian Republic concerning priorities for implementing and improving equal rights. Article 15 of the Law on Equal Treatment states that complaints, that are connected with equal rights, that have been violated, are analysed according to the same procedure as is envisaged in the Law on Equal Opportunities of Women and Men. Article 24 of this Law gives the Ombudsman the right to pass one of the following decisions, which can be divide into few types: (a) judicially binding decisions ( such as administrative penalties); (b) decisions, which do not create direct rights or obligations for the participants (such as recommendations to stop discriminatory actions, etc.); (c) decisions, which defend the public interest (after determining that an act is criminal, the material of investigation is transferred to the procurator). In this article, an overview of the essential features of each of these types of decision will be provided.

\section{JUDICIALLY BINDING DECISIONS OF THE EQUAL OPPORTUNITIES OMBUDSMAN}

Binding decisions are only a small part of the Equal Opportunities Ombudsman's decisions. However, they are very important in terms of their legal power. In Article 24 The Law on Equal Opportunities of Women and Men it is noted that during or after an investigation the Ombudsman can make a decision to begin analysing an administrative violation case and impose administrative sanctions. The same regulation is in the Regulations of the Office. So, among the Ombudsman's competence there is also the right to hear administrative violations cases, which is envisaged in Article 247 of the Administrative Law Violations Code (further-ALVC). The 1st part of this article makes it clear that the Office analyses cases of administrative violations according to Articles 41 and 187 of the ALVC. In Article 41 the responsibility for violating the equal opportunities of women and men, as stated in the Law on Equal Opportunities of Women and Men, 
is described; Article 187 envisages responsibility for noncompliance of the demands of the Equal Opportunity Ombudsman Office. As an administrative institution, punishing for administrative law violations, it becomes a kind of court, acting in the judiciary field ${ }^{23}$, so the Ombudsman's Office, which analyses administrative cases and imposes sanctions, may be treated as a kind of court in this aspect.

It should be noted that the Ombudsman is not obligated but has only the right to analyse administrative violation cases. In Vilnius, in Regional Administrative Court decision, No. I-243-602/2009, there is an explanation of this discretionary right, that the Ombudsman holds: a refusal to investigate an administrative violation case cannot be treated as an act of noncompliance on the part of the Ombudsman's competence and no court decision may request such an investigation. In practice, the Ombudsman uses this opportunity very rarely. It is written in the Ombudsman's Office report for the years 2008 and 2009 that administrative sanctions were provided only in 1 per cent of the Ombudsman's decisions in 2008, while in 2009 they were not imposed at all. In the opinion of the Ombudsman's Office, imposing an administrative sanction is involves a lot of difficulties, because it can be imposed only on a physical entity and it does not resolve the conflict. When levelling a financial penalty, an injured party is not compensated directly neither for pecuniary nor for non-pecuniary damage, and the offender, who only pays a small sum of money, in most cases does not change his illegal activities ${ }^{24}$. Evaluating these aspects, imposing administrative sanctions, despite their judicial power, does not seem to be very effective.

\section{JUDICIALLY NON-BINDING DECISIONS OF THE EQUAL OPPORTUNITIES OMBUDSMAN}

Another type of Ombudsman's decision, embed in Article 24, p. 2 of the Law on Equal Opportunities of Women and Men, gives the Ombudsman the right, when carrying out an investigation or having just finished one, to demand that a particular person or institution cease and desist those actions, which violate the principle of equality, or to change or withdraw the act in question. The Ombudsman uses this right often. In the activity reports of the Ombudsman's Office it is noted that demanding that offenders cease and desist from their violations comprised 22 per cent of all its decisions in 2008 , and 27 per cent in 2009. When such an institution changes or withdraws the legal act which consists of the discriminatory provisions, this type of Ombudsman's decision directly and positively influences the rights and opportunities of many people (the injured party as well as the offender and other subjects) in the field regulated by the appealed legislation. With the help of these kinds of decisions, the Ombudsman acts as a mediator between the injured party and the offender. When the

23 Darius Urbonas, Jurisdictional activities of quasi-judicial institutions in imposing administrative sanctions (Doctoral Dissertation Social Sciences, Law) (Mykolas Romeris University 2007).

24 The report of the Office of Equal Opportunities Ombudsman (2008), http://www.lygybe.lt/?pageid=7accessed 19 August 2014. 
institution-offender refuses to implement the given recommendations, the injured party can defend his/her rights in court, using factual circumstances and the formulated recommendations of Ombudsman's Office as official evidence in the case. It is not noted in the annual reports of the Office how many recommendations were taken by offenders of their own free will. This type of information would be very valuable and is made available in other countries (for example the French Ombudsman's Office provides it ${ }^{25}$ ). It is notable, that even if these decisions are not binding, recommendations of this sort by the Ombudsman or even the opinion of this Office on any specific question has a positive influence: firstly, society is shown a desirable standard of behaviour, secondly, the offender's reputation is damaged. The Ombudsman's Office maintains a continuous dialog with the mass media, what raises its authority and ensures that the results of its activity become known because, according to A. Žvinklienè, 'The Ombudsman's institution should not only provide information of its effectiveness but it must also take into consideration other opinions - get feedback' ${ }^{26}$. The Equal Opportunities Ombudsman's Office shows that 'an active, two-way and even communication is ongoing between the Ombudsman's Office and the mass media' and 'the two parties give each other advice, comment on and react to one another's actions ${ }^{27}$.

\section{The Function of the Public Interest Defence as PART OF THE ACTIVITY OF THE EQUAL OPPORTUNITIES OMBUDSMAN}

After an evaluation of the legislation of other countries, which regulate the activity of similar institutions, it can be stated that in the Lithuanian legal system the Ombudsman's Office has quite a narrow competence as concerns defending the public interest. Only one function is envisaged for the Office pertaining to this type of defence - the right to transfer the investigation material to the procurator or a particular pre-trial investigation institution. The Ombudsman uses this right rarely enough: in 20088 per cent, and in 20093 per cent of all complaints ended by referring the investigation material to certain pre-trial institutions. In foreign countries the opposite practice can be seen. For example, the Equal Opportunities Centre of Belgium, the Equality Leadership of Ireland, and the Commission of Equal Opportunities of Denmark have a wider function such as the right to proceed against discrimination in the court directly. For example, the Belgian Equal Opportunities Centre exercises this right when an act of discrimination is repeated, but when there is no one who can be

\footnotetext{
25 Annual report (HALDE 2009).

${ }^{26}$ Alina Žvinklienè, 'Socialinè lygių galimybių kontrolieriaus tarnybos refleksija: Lietuvos „Web 2.0 bendruomenès“ atvejis' (2012), < http://www.lstc.lt/leidiniai.php > accessed 19 August 2014.

27 The report of the Office of Equal Opportunities Ombudsman (2010), http://www.lygybe.lt/?pageid=7accessed 19 August 2014 .
} 
sued personally to the court; also in cases, when it is impossible to identify the victim, but it is necessary to stop the act of discrimination immediately ${ }^{28}$.

Most institutions of Equal Opportunities use an active strategy for solving discriminatory cases for the purpose of creating effective changes in society. It is possible to take note of some important cases which were successful for the institutions, by implementing the equality principle, and using their rights to defend the public interest with maximum efficiency as in the practise of the European Union Justice Court (EUJC) ${ }^{29}$. In such cases the British antidiscrimination law acts were compared with the purposes of the Directives and it was decided that establishing a different pension age for women and men was illegal and the compensation limit for violating the equality of the sexes was abolished.

Lithuanian law, which regulates the status of the Ombudsman's Office, does not provide the institution with the right to go to court directly with the intention of defending the public interest ${ }^{30}$. As the experience of other countries has shown (e.g. Great Britain), institutions, whose goal is to fight effectively against discrimination, have the opportunity of locus standi (the right to address the court) even when this right is not provided for directly in legal acts ${ }^{31}$. It is possible to consider articles of the CPC and the Law on Administrative procedure, which regulate the defence of the public interest as well as the EUJC practice ${ }^{32}$ makes presumptions for the Ombudsman Office to apply to court directly in cases when a discriminating act violates not only the interest of a single individual but the interests of a group of people, and these court cases become the aim of defending the public interest ${ }^{33}$. According to this interpretation, the Ombudsman Office has the right to apply to court independently under the condition that there is a clear need to defend the public interest. When the court raises the question of an existing necessity to defend the public interest in a specific situation, it should be analysed, if there are conflicting interests between the interests of a particular person or group of people, the particular values, which are embodied in the Constitution and defended by it would be violated.

Also it is necessary to point out that in Article 49, the 2nd part of the CPC grants the right for the parties of a civil procedure to request that the court involve an equality institution in order to draft a conclusion. In discrimination cases, this institution is the Ombudsman's Office. The Law on Administrative Procedure does not use the concept of ,the institution, providing a testimony". Article 48 states that in administrative case disputes (e.g. labour arguments) the parties are an applicant and a defendant. Parties in administrative cases are: an applicant (a person who registers a complaint or instigates an inquiry); a defendant (an institution, an officer or a person, whose acts or actions are being appealed); the third person(s) of interest

\footnotetext{
${ }^{28}$ Schiek, Waddington, Bell (n 8).

${ }^{29}$ Marshall v. Southampton Area Health Authority [1991] C-271/91.

${ }^{30}$ Edita Žiobiene, 'Problems of the Legal Status of the National Equality Bodies' (2006) 90 (12) Jurisprudence.

${ }^{31}$ Schiek, Waddington, Bell (n 8).

${ }^{32}$ Centrum voor gelijkheid van kansen en voor racismebestrijding v Firma Feryn NV [2008] C 54/07.

${ }^{33}$ Law on Administrative procedure Of Republic of Lithuania [199] OJ 13-138 (Art. 56, part 1); Code of Civil Procedure of Republic of Lithuania [2002] OJ 36-1340 (Art. 49).
} 
(whose rights or duties may be influenced by the decision in this particular case). The participants of administrative cases are: the parties of the trail and their representatives, also the procurator, administrative subjects, organizations and physical entities, who participate in defending the public interest (those who initiated the case). This means that the Ombudsman's Office is not able to participate in the administrative trial as ,,an institution, providing testimony", and as one of the functions of Ombudsman Office this makes the defence of the public interest, more complicated - it shows the incomplete implementation of the goals, as envisaged in the Directives. Article 61 of the Law of Administrative Procedure envisages that a specialist may be invited during the trial, when special knowledge for analysing and evaluating documents, things or acts is necessary for a case hearing. Such a specialist provides testimony with regard to certain questions, given to him by the court. Whereas the Ombudsman Office's specialists are knowledgeable about discrimination, they are supposed to be a part of the case and provide testimony as to the existence or non-existence of discrimination as fact or any other evaluations. The main reason for inviting a specialist to court is to prove that there is a need for expert knowledge in a case. The fact that the Ombudsman is interested in defending victims of discrimination and promoting equal opportunities does not mean that he/she will not be able to give objective and impartial testimony ${ }^{34}$. In different cases people with different qualifications are utilized as specialists: the director of The Communications Regulatory Authority's Telecommunications department, a professor from Vilnius University's Economy / Marketing Department, a consultant from the Health Care Ministry, a specialist in the Science of Religion - they have all been utilized in order to provide their expert testimony in court hearings. That is why it is reasonably assumed that the personnel of the Office are able to provide expert testimony about questions related to discrimination.

It should be noted that the legislation of other EU countries such as Hungary or France, which regulate the activity of equality institutions, give them the right to participate in cases where discrimination questions are analysed $^{35}$. This is viewed as being positive since it is only in this way that institutions of equality can carry out their mission and implement the principle of equality.

\section{DECiSion, STATEMENT AND TESTIMONY OF THE EQUAL OPPORTUNITIES THE OMBUDSMEN}

One of the most problematic issues of Ombudsmen's status in general is the form and power of his decisions. It should be noticed that legal regulation do not clearly determines what form the Ombudsmen's decision should take. According to Article 23, part 4 of the Law on Equal

\footnotetext{
${ }^{34}$ Equinet Report, Influencing the law through legal proceedings - the powers and practices of equality bodies (Equinet 2010).

${ }^{35}$ Schiek, Waddington, Bell (n 8).
} 
Opportunities of Women and Men, after an investigation into a complaint, a statement, signed by the Ombudsman must be prepared. Another regulation is stated in the Regulation of this institution. The 11th subsection of Regulations states that after the investigation of a complaint the Ombudsman can write down the conclusion of a case. There is no legal act, which identifies in what cases the Ombudsman should formulate his decision in the form of statement, and in which cases in the form of testimony. It should be considered that the Ombudsman should provide testimony to the procurator or the court, in civil procedure, where there was a request to defend the rights of the victim. A statement should be written down after an investigation into the complaint of an applicant. The Office, having already investigated the complaint, has the right to pass one of the decisions, provided by Article 24 of the Law on Equal Opportunities of Women and Men.

The status of the Ombudsman's Office in civil procedure, which arises from a suspected violation of the principle of equality, is regulated by Article 49 of the CPC. This provision states that state or municipal institutions can be participants in a trial, in cases, when they are asked or of their own initiative provide testimony in a civil case in order to fulfil their duties, related to the defence of the public interest. It should be noted that in Lithuania certain judicial practice is beginning to form: the Office is incorporated into the civil trial as an institution, which provide testimony at the request of parties or the court ex oficio ${ }^{36}$.

Summarising all listed information of this section, attention should be paid to the necessity to stimulate the formation of unified judicial practise. Despite the fact, that there is no consensus as to the form of the Ombudsman's decision, the statements should be presented after an investigation into the applicant's complaint and the testimony, should be referred to the procurator or the court upon request during the civil procedure in cases where the defence of a person's rights has been requested because they are being discriminated against.

\section{Mediation}

Mediation in Lithuania is a widely-discussed question. This alternative method of dispute resolution is commonly recognized as a good choice for disputing parties in various social conflicts. Thus, in Lithuania, this social innovation is rarely applied in practice and then, not in a proper way. It mostly takes place, because of a lack of information and judicial regulation in certain fields. For example, legal competition between the processes of mediation and conciliation often occurs. This problem becomes more and more common in the connection with supervising the implementation of the equality principle. Article 24, in the 5th subsection of the Law on Equal Opportunities of Women and Men states that during the process of investigating a case, the Ombudsman has the rights to stop it, when ,an applicant and an offender reconcile“. The possibility of ending the investigative process is quite often applied in practise that is why it is worth

${ }^{36}$ Kaunas County Court, civil case No. 2-1105-527/2010; Vilnius County Court, civil case No. 2-1189-545/2008 
discussing the discretion of the Ombudsman in the process of reconciling the parties. None of the legal acts which regulate the activity of the Ombudsmen Office does not provide or explain in detail what the reconciliation role of the Ombudsman is. It should be noted that EU institutions, in implementing the equality principle, apply mediation widely ${ }^{37}$. It is explained that, if during the mediation process, the two parties reach a compromise, it will be easier for the victim to get back to his/her work and the possibilities of further discrimination or harassment become lower. So, evaluating the predicted results of applying this alternative dispute resolution process, it can be stated that with its help the main aim of the antidiscrimination law would be implemented completely. The victim would revert back to the initial situation, that which pre-dates his/her rights being violated.

It should be remarked that the Ombudsman's Office often applies only an informal procedure of mediation, when the Ombudsman or other officers of the Office tries to help parties solve their dispute peacefully. This practise should be evaluated ambiguously. The choice to try and resolve a conflict with the help of an alternative process can without a doubt the positively evaluated because it helps to re-establish peace between the parties and demonstrates the good will of the conflicting parties and mediator, who helps them to reach an agreement. However, there is the risk of misuse of this dispute resolution process, what can result in even negative results. Applying mediation to the implementation of the equality principle, first of all, demands a certain legal background, secondly it is necessary to understand what kind of phenomenon mediation is and how such a process should be organised. In scientific literature mediation is often understood as an informal trial, one in which an impartial third party, without the right to pass a compulsory decision, helps the parties to reach a conclusion suitable for both parties ${ }^{38}$. A mediator, using certain methods, his/her professional experience, and expertise, negotiates with the parties and, using certain actions, moves them in a positive direction with the goal of finding a mutually acceptable solution. By carefully listening, and offering different non-compulsory proposals, the mediator leads the parties to reach an agreement. That is why; it is obvious that aspects of using mediation such as: objectiveness and lacking the power to make certain decisions is very important. Otherwise, the mediation of the Equal Opportunities Ombudsman cannot fulfil these demands. Another aspect of the problem: the need for a highly competent and specially qualified mediator. Nowadays in Lithuania there are no specialists like this in the Ombudsman's Office. Despite these listed criticisms, mediation could be successfully applied to the Ombudsman's activity if it was suitably regulated. In 2009 the Ombudsman's decisions to complete an investigation, because of the reconciliation of the parties involved, comprised 34 per cent of all its decisions to stop cases. It should be stated that this institution and its potential to bring more and more disputes to peaceful conclusions, should

${ }^{37}$ Schiek, Waddington, Bell (n 8).

${ }^{38}$ Robert Baruch, Joseph Folger, The Promise of Mediation (Jossey-Bass Publishers 2004). 
be analysed as a possible area for the application of mediation, as an effective tool for the prevention and resolution of social conflicts.

\section{LEGAL EFFECT OF THE DECISIONS OF THE EQUAL OPPORTUNITIES OMBUDSMAN}

In legal acts which regulate the activity of the Ombudsman's Office, the legal power of the decisions of this institution has not been determined. This uncertainty in Lithuania has led to a situation, in which the Ombudsmen's decision is appealed to the administrative courts or to the Chief Administrative Disputes Commission (CADC) as the pre-trial stage institution of a administrative trial. The number of these cases is not large, but analysing the judicial practice of the administrative courts it is notable for its heterogeneity and ambiguity. According to the information, provided from the Office, the issue of possibility to appeal the decisions of Ombudsperson in practise arises quite rarely. Even if such decisions are appealed, the court decisions normally confirms the position of Office ${ }^{39}$. More often Office is involved in judicial proceedings as an institution, which is asked to present and conclusion (amicus curiae) on the issues, related with the need of special knowledge in the field of anti-discriminatory national and international law provisions. Thus the issue of possibility to appeal such decisions must be clarified. In the number of cases, with similar content, the question of appellation in general, was differently solved. In one group of cases the complaints against the Ombudsman's Office decisions were investigated essentially ${ }^{40}$. The validity or invalidity of these decisions was stated. In another group of cases, courts decided to stop the trail $^{41}$. It should be noted that in these types of cases the Office participates as a respondent according to the Constitution and Law on Administrative Proceedings (it is envisaged that each interested subject has the right to go to court, in order to defend his/her violated rights or legal interest). In this part of the article, this problem will be analysed more detailed.

Having in mind that court practise on the issue of legal power of the decisions of Office is irregular, it is necessary to review the decisions of courts, where the right to appeal was confirmed. Also so it would be valuable to compare the status of Equal Opportunities Ombudsman's decisions with decisions of Parliament Controllers, who also confirm the requirements of classical Ombudsman institution.

The Supreme Administrative Court of Lithuania in decision No. A525-825-08, where a case of sexual harassment was investigated, stated that „The Office of Equal Opportunities of the Ombudsman's legislation provides certain functions of public administration. These functions should be performed in the whole country. All decisions, which have judicial consequences, passed by the Ombudsman should be treated as

39 The report of the Office of Equal Opportunities Ombudsman (2013), http://www.lygybe.lt/?pageid=7accessed 19 August 2014.

40 A.R. v Equal Opportunities Ombudsman's Office [2008] A-525-825-08.

${ }^{41}$ R.J. v Lithuanian Republic, represented by Equal Opportunities Ombudsman [2009] I243-602/2009; Public Company "Vilniaus miškų uredija" v. The Office of Equal Opportunities Ombudsman [2010] I-342-602/2010. 
administrative acts, adopted by the central public administration, and according to the ACPL, article 15, subsection 1, part 1, should be investigated by the Vilnius Regional Administrative Court or according to Article 22, in the 4th subsection of the ACPL - in the Chief Administrative Disputes Commission" 42 . The Court came to the conclusion that the law allowed The Chief Administrative Dispute Commission to solve disputes based on the validity of the decision of the Ombudsman, as a subject of the central public administration. Also it was noted that the fact that "The Office is not ascribed to a category of executive institutions, does not mean that the Ombudsman does not fulfil public administration functions. From the content of the Law on Equal Opportunities of Women and Man (Articles $10,12,18-24)$ it is obvious that legislation entrusted to carry out certain functions of public administration, as an investigation into complaints and passing decisions" ${ }^{43}$. According to the Article 3, subsection 1 of The Law on Administrative Proceedings, the administrative court analyses disputes in the field of public administration. Article 25 of the above-mentioned law states the order in which a case is investigated in the pre-trial stage. It is stated in the first part of the article that before appealing to the court, the individual legal acts or actions (and omissions), taken by public administration subjects listed in the legislation, can be argued, referring to the pre-trial, and unconnected to the court, institutions. Article 9 of the Law on Administrative Disputes Commissions states that The Chief Administrative Dispute Commission investigates complaints into the validity of individual administrative acts or actions, fulfilled by central public administration subjects.

In other administrative case ${ }^{44}$ the Supreme Administrative Court stated that the right to appeal the decisions of Equal Opportunities Ombudsman decisions is not absolute. It covers only these situations, when the decision of Equal Opportunities Ombudsperson has an influence towards the rights and the interests of the party, who initiates the appellation process, or when the person, who presents an appeal claim, is authorised to defend public interest. If evaluate these decisions ${ }^{45}$ systematically, it is clear that court practise arises rule, that Equal Opportunities Ombudsman decisions in every case must be checked whether it has any possibilities to create legal consequences for the person, or not.

Issues related the legal scope and consequences of the decisions of other Ombudsmen, operating in Lithuania, has previously been interpreted by the courts. For example, in administrative case No. A-15-1982/2006 ${ }^{46}$ the court explained that attempting to determine whether the Parliament Controller's final act of investigation must be treated as a public administration decision, which would have an influence on the appearance, alteration or termination of an applicant's rights or duties, or as a violation

\footnotetext{
${ }^{42}$ Supreme Administrative Court of Lithuania [2008] A-525-825-08.

43 ibid.

${ }^{44}$ Supreme Administrative Court of Lithuania [2013] A492-2078/2013.

45 ibid.

${ }^{46}$ Supreme Administrative Court of Lithuania [2006] A-15-1982/2006.
} 
of his/her legal interests. In the opinion of the court, it is necessary to take into account the legal consequences of such a statement. Having analysed the Parliament Controller's rights, stated in Article 19, subsection 1 of The Law on Parliament Controllers, the court made a decision that the final acts of the Parliament Controllers are only recommendatory and do not create any rights or duties for an applicant nor for the public administration subject, whose decisions, actions or omission were the source of the complaint. So it should be treated neither as individual legal acts nor as legal norm acts and cannot be appealed to the administrative courts. The Supreme Court of Lithuania in 2010 stated that administrative courts are not competent to deal with decisions of Parliament Controllers as an appeal instance, because its character is only recommendatory, which legal power is based exclusively on the authority of such institution ${ }^{47}$. It should be mentioned that in the very beginning of activities of Parliament Controllers bodies, its decisions were a subject to appellation. This regulation was changed in 2007. Today in Law on Administrative Proceedings is clearly stated, that administrative courts are not competent to deal with appellations on decisions of Parliament Controllers (despite of the fact, that in Lithuania other Ombudsmen institutions also are functioning). According to scholars, "the legislator, who made these changes, paradoxically do not noticed the necessity together made analogic reservations in regard of impossibility to appeal for administrative court the decisions of other Ombudsmen, such as Equal Opportunity and Child's right protection Ombudsmen, thought the legal origin of their activities is the same, still their decision may be appealed"48. Also it should be marked, that no doubly the decision of Parliament Controller, especially if the bureaucracy, abusive behaviour of certain officer or other violations of human rights are stated, in some situations can have negative influence and even create some material of immaterial damages. Also in such cases, when Parliament Controllers take obligatory to implement decisions, it cannot be named as "recommendatory" ones. Moreover, according to scholars "Parliament Controller is not protected from mistakes. In human rights preservation attitude, absolute impossibility to appeal the decisions of Parliament controllers is problematic, especially in situation, when the Law on Parliament Controllers do not have any provisions, regulating appellation of taken decisions in cases, when there circumstances, which shows the risk, that mistakes were made or incorrect interpretation of legal acts were performed"49. Very important is a fact, that according E. Küris, impossibility to appeal the Parliament Controllers decisions, was raised because of the need to guarantee the independence of these bodies from other branches of power, including judicial power ${ }^{50}$. Of course independency is an important factor of the creation of authority of each Ombudsperson, still the right to defend violated rights is a Constitutional principal, which should not be scarified, but balanced and clearly identified in laws.

\footnotetext{
${ }^{47}$ Supreme Court of the Republic of Lithuania [2010] 3K-2-141/2010.

${ }^{48}$ Küris et al. (n 12).

${ }^{49}$ ibid.

50 ibid.
} 
It was already mentioned, that according to the court practise, decisions of Ombudsman, which create certain legal consequences for a person, may be appealed. The essential feature of the individual administrative act is providing concrete judicial consequences for a certain person or group of people. The decision of the Ombudsman in most cases does not directly evoke any rights or duties for the offender (except the decision to level an administrative penalty). After an investigation of the complaint the Ombudsman signs a statement, which during the investigation reveals the pre-determined conditions, collects evidence and a judicial evaluation of the actions taken. In this case no compulsory decision is formulated. This means that it has no direct influence on the rights and obligations of an applicant or other trail participants. If the impact cannot be determined, it is impossible to apply to the court with a demand for the withdrawal of this type of decision. The Ombudsman's decision (a statement or conclusion) can be treated as written evidence (official evidence, according to CPC, Article 197, subsection 2) in a court procedure, which would resolve civil or administrative cases related to illegal exemption work, a diminishment in salary, damage compensation etc.

In administrative case No. I-243-602/200951, the Vilnius Regional Administrative Court stated that argument of written evidence cannot be understood as an application to the court with separate demands. It should be understood as a need to give other evidence which deny the content of the disputed evidence. An applicant has the right to implement his rights by initiating a trial process, the end of which could independently influence his rights and duties. An administrative procedure cannot be considered as an additional measure of evidence in civil or other administrative case. Article 3 of the Law on Administrative Proceedings states that the administrative court hear disputes in the field of public administration or internal administration. The court is obligated to ensure the reestablishment of the rights or freedoms of a person that have been violated and to reject unreasonable demands. The Vilnius Regional Administrative Court explained these legal norms similarly in case No. I-342-602/2010: "Whereas the Equal Opportunities Ombudsman's Office does not pass decisions of a compulsory nature, thereby creating obligations and rights for others, a statement, which determines that there has been a violation of the Law on the Equal Opportunities of Women and Men, and a warning to the offender may, by such decision, may not be treated as administrative act. Considering the fact, that the statement of the Ombudsman does not create any judicial consequences and a separate case on the issue of withdrawing such a document cannot be initiated, without an order of volitional purpose from the side of the subject of the public administration, no influence towards the rights and obligations of a person can be done" ${ }^{, 52}$. The European Court of First Instance stated that decisions of the European Ombudsman cannot be appealed according to Article 230 of the European Community

${ }^{51}$ Vilnius Regional Administrative Court [2009\} I-243-602/2009.

52 Vilnius Regional Administrative Court [2010] I-342-602/2010. 
Agreement ${ }^{53}$. One of the main features of the Ombudsman Institution is that it does not have the right to apply compulsory legal measures and acts only with the help of the ,power of authority“. Implementing the decisions of the Ombudsman shows that the public administration institutions respect human rights that they are trying to improve their activity in this area ${ }^{54}$. Despite the recommendatory value of the Ombudsman's decisions, these decisions in countries where the rule of law principle is preserved are ,implemented as an authoritative opinion ${ }^{655}$. It should be noted that in separate European countries institutions, ensuring the equality principle, acts as a different status. The closest institution to the Lithuanian Ombudsman is in Sweden. The Swedish Ombudsman's Office has been active for more than 200 years. It is an independent and objective body, and its decisions are final and undisputed. It should be remarked that "Ombudsman offices play a serious role in strengthening democracy, the rule of law and civil society" why the legal scope of these bodies' decisions must be made clear.

It should be considered, that after evaluating the whole of the Ombudsman's decisions, the presumptions to appeal these documents can appear only in one case - the demand to withdraw an administrative sanction, imposed by the Ombudsman. In the authors' opinion, this is the only situation, in which the decision of the Ombudsman can directly influence the rights and obligations of the offender. A judicial practise, based on the issue of the possibility of appealing the decisions of the Ombudsman to a court or pre-trial institution, must be criticized as violating jurisdictional rules; the principle of the separation of power. The usage of this practise would diminish the authority of the equality institution and its power to form a state equal opportunities policy.

Analysing the provisions of the Law on the Equal Opportunities of Women and Men, it is obvious that the activities of the Office, related to the investigation of complaints in the area of discrimination or harassment are regulated not by Public Administration Law but by a Special law, which states that the Ombudsman can investigate complaints both in public and in private sectors. This fact may be presented as an important evidence, that decisions of this Ombudsman cannot be treated as public administration activities in all it's scope. It has also been determined that the purpose of a complaint investigation is to better understand the seriousness of the circumstances, to collect evidence and to evaluate the actions taken by the suspected offender. In our authorial opinion, the conclusion lies in the reality of the Ombudsman's Office which does not perform only public administrations functions. It cannot be denied its impact towards private sector. It shows the need for special attitude and special legal regulation on this issue.

The authors' emphasize the need to improve the existing Equal Opportunities legislation by amending the main legal acts with the provision

\footnotetext{
53 European Court of First Instance [2002] T-209/00.

${ }^{54}$ Pranevičienè (n 13).

55 Saule Vidrinskaite, 'The Parliament Ombudsmen in the system of authority institutions' in Vesta Adomaitienè (ed), Lithuanian Constitutional Law: Development, Institutions, Protection of Rights, Self-Government (Mykolas Romeris University 2007).

56 Edita Žiobienè, 'Reform of the Ombudsman Institutions in Lithuania' (2010) 119 (1) Jurisprudence.
} 
clearly and concretely stating the legal scope of decisions of the Equal Opportunities Ombudsman and the possibilities to appeal them only in the case of the imposition of an administrative sanction. Such explicitness is necessary in order to secure the high authority of this institution in society and to maintain the homogeneity of judicial practice on this issue.

\section{CONCLUSIONS}

1. The Office of the Ombudsman should be treated as an institution of the non-classical Ombudsman, which acts in both public and private fields of law, but is a specialised institution, which investigates only one kind of complaints - the violations of equality, on the grounds of sex, race, ethnic origin, age, nationality, sexual orientation etc. The establishment and activity standards of this institution are legitimated by the UN Paris principles.

2. The Office is not a compulsory pre-trial institution. The Ombudsman's decisions can be divided into a few kinds: (a) judicially binding, (b) decisions, which do not directly create rights or obligations for the participants of the legal relation; (c) decisions, defending the public interest.

3. The Office of the Ombudsman can pass only one judicially binding decision, one which acknowledges the person guilty for committing an administrative law violation, for which an administrative sanction may be imposed. An administrative penalty as a judicially binding consequence may be appealed according to the regulations, provided by the Law on Administrative Proceedings.

4. Judicially non-binding decisions of the Ombudsman have the official status of written evidence and can be used in civil or administrative procedures, when a question of illegal termination arises, salary diminishment and others, related to violations of the equality principle. It should be noted that these types of Ombudsman's decisions should not be appealed.

5. The legal functions of the Ombudsman's Office in the area of defending the public interest includes the Ombudsman's right to refer the investigation material to a procurator or pre-trial investigation institution in cases, when a criminal act is suspected. The proposal is given to the Office of the Ombudsman to use locus standi, which is provided by CPC and the Law on Administrative Proceedings, and provides the right to directly initiate court cases against discrimination, when the public interest needs to be protected.

6. The reconciliation or mediation process of the Ombudsman's Office is not regulated by legislation. Regulation is recommended with reference to the Ombudsman's Office mediation procedure.

7. Despite of current court practice, which is irregular, it should be noted that only one type of Equal Opportunities Ombudsman's decision the decision to impose an administrative penalty - can be appealed. 
8. The legal power of the Equal Opportunities Ombudsman decisions should be described clearly and concretely in legislation, concerning this institution; otherwise the authority of this institution in society will be endangered and uncertain. 